\title{
A Personal Note on \\ Open Access in Linguistics
}

\author{
Stefan Müller \\ Freie Universität Berlin
}

\begin{abstract}
This paper contains only known facts about open access, but they are put into a rather personal perspective that may help others to understand the importance of Open Access in science in general, and in linguistics in particular.

This paper tries to motivate Open Access publishing, with a particular focus on publishing books. In Section 1, I describe the problems in accessing relevant information in economically weak countries, the problem of underpayment in the humanities, and usage restrictions of traditionally published books. Section 2 explains the factors that contribute to book prices. Section 3 briefly describes Open Access publishing and print on demand services. In Section 4, I address some challenges for Open Access publishing and suggest ways to ensure quality control, proper typesetting, and efficient marketing. Section 5 discusses Open Access approaches of profit-orientated publishers. Section 6 deals with Open Access and getting tenure and promotion, and Section 7 is about radical opinions about copyrights outside of academia.

In order to make the situation in science more understandable to people living in the US and Western Europe, I want to describe my personal experiences in an Eastern Block country in the following subsection. I will then turn to book prices in relation to underpayment in the

Keywords: Open Access, Linguistics, Precariat, Rock'n'Roll
\end{abstract}


Figure 1:

Form confirming that publications were confiscated
Zollverwatiung

der (Kopfstempet) at: dic. Republik

Grenzzollomt Schönefeld

1189 Berilin-Schönefeld

Einziehungsentscheid A 097158

Die Einziehung der nachfolgend genannten Gegenstände erfolgt nach $₫ 16$ Zollgesetz vom 28.3.1962 (GBl. I Nr. 3 S. 42) *wegen Verstoßes gegen $\$ ₫$ 7, 9 Zollgesetz, $\ 15$ der 11. Durchführungsbestimmung zum Zollgesetz vom 12.12.1968 (GBl. II Nr. 132 S. 1057)

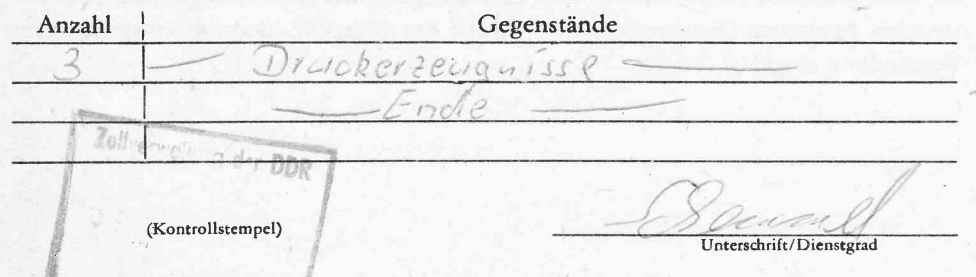

*in der Fassung des Anpassungsgesetzes vom 11.6.1968 (GBI. I Nr. 11 S. 242) und des Gesetzes zur Än "ng und Ergañzung des Zollgesetzes vom 28.6.1979 (GBl. I Nr. 17 S. 147)

Blatt 1 Zur Aushändigung/Zustellung

ZV 184 ZV 184 VV Halle Ag 309/81 III/4/14 $17232 / 184$ 20,0 Bl $2 \times 50$ (12496)

humanities even in relatively rich countries in Section 1.2, and turn to usage restrictions for everybody in Section 1.3.

\subsection{Accessibility of Information in Economically Weak Countries or Countries with Censorship}

I was born and raised in the GDR. Since my school had connections to the Humboldt University, I was able to participate in individual tutoring in computer science. This was in 1986 and the subject computer science did not exist back then at the Berlin universities. It was only introduced at the Humboldt University in 1987 as a specialisation of the mathematics curriculum. The individual tutoring was done in the main computing centre of the Humboldt University. The computing centre had one machine with $128 \mathrm{~K}$ memory. The lessons were held for a friend of mine and me by two really friendly and knowledgeable guys who did this as their gesellschaftlich nützliche Tätigkeit. ${ }^{1}$ As a participant in these lectures, I was in a very privileged

\footnotetext{
${ }^{1}$ People in the GDR were expected to work for society in their spare time. Apart from the implicit pressure to take part in this system, this was a good thing since, among other things, researchers offered classes for pupils in various subjects. The Mathematical Pupils Society still exists: http://didaktik1.
} 
situation since I had access to terminals and could type my programs using the editor $\mathrm{ED}^{2}$. This was very cool because here I sat as a 16year-old in front of a screen while the students were typing punched cards, ${ }^{3}$ which they then handed in for processing only to find out a week later that they had a typo on the tenth card. However, there was a downside to working at the terminal in the Humboldt University: after typing away for ten minutes, the system crashed and took 20 minutes to reboot. Fortunately, my school had connections to another scientific institution in Berlin: the Zentralinstitut für Kybernetik und informationsverarbeitende Prozesse (ZKI, Central Institute for Cybernetics and Information Processing). This institution had a Unix group for which I worked as part of the school education (Wissenschaftlichpraktische Arbeit $\mathrm{WPA}^{4}$ ). Here I could work (using ED) on an SM-4 ${ }^{5}$, a Polish PDP-11 clone.

Now for the publications: of course there were no text books on computer science available at that time in the GDR. Remember, the subject did not even exist back then. So what could people do to get the information they needed? Books? Journals? Magazines? They had to get it via private channels from the West. This was bad luck for me, since I did not have any relatives in West Germany. One could try and bring material in via Hungary, but this was as unpleasant as getting it over from West Germany: if you got caught at the border, the material got confiscated. See Figure 1 on the facing page. In the 50's you even went to prison if you were caught with the wrong type of publication. For example, Manfred Bierwisch was arrested for possessing the journal Der Monat and was sentenced to 18 months and actually spent 10 months in prison. ${ }^{6}$

While working at the Humboldt University, I had access to Kernighan and Ritchie, 1978, a book that describes the programming language C. This book was somehow imported from the West and then typed in at the University of Karl-Marx-Stadt (the city with

\footnotetext{
mathematik.hu-berlin.de/index.php?article_id=11.

${ }^{2}$ http://Www.gnu.org/fun/jokes/ed-msg.html. 19.09.2012.

${ }^{3}$ http://en.wikipedia.org/wiki/Punched_card. 19.09.2012.

${ }^{4}$ http://de.wikipedia.org/wiki/Wissenschaftlich-praktische_ Arbeit. 19.09.2012.

${ }^{5}$ http://en.wikipedia . org/wiki/SM - 4. 19.09.2012.

${ }^{6}$ http://de.wikipedia.org/wiki/Manfred_Bierwisch. 23.09.2012.
} 
Figure 2:

Kernighan and Ritchie as it was read in the GDR

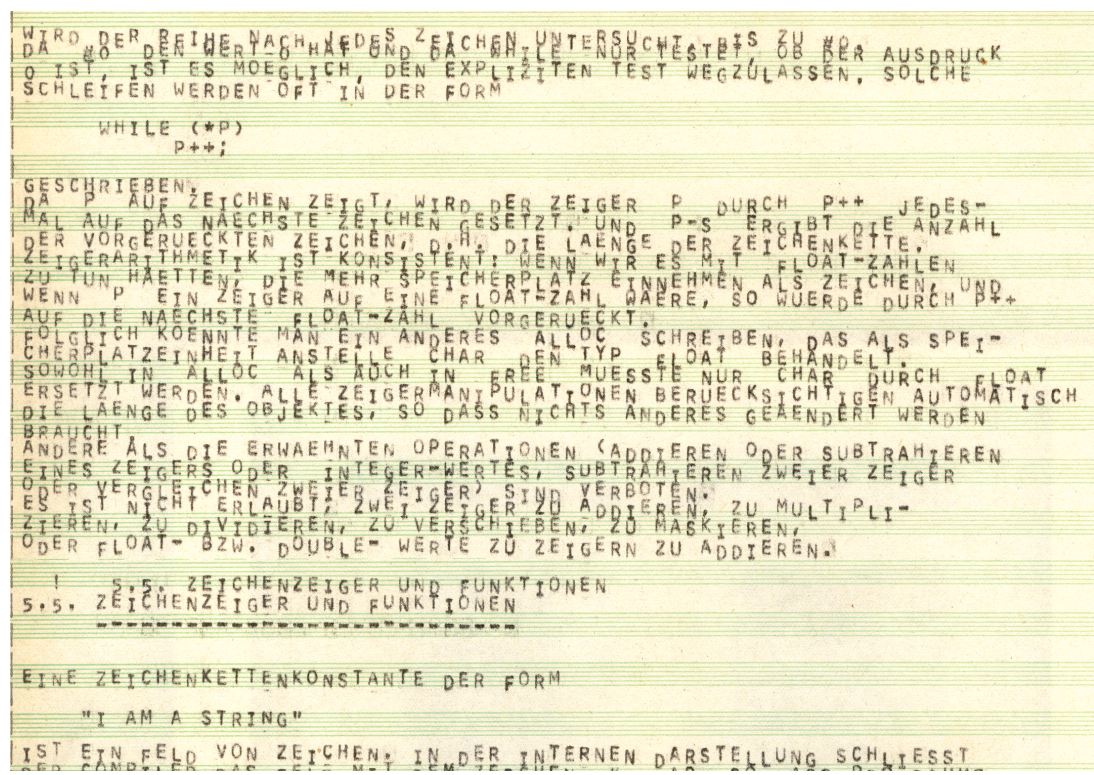

three 'o's, now called Chemnitz). The sysadmins had a copy of the file and printed it for me on their parallel printer. There was a problem with the printer though: the type wheels were out of sync and so the letters were dancing. See Figure 2. But the good thing was: I read the book in the tram and these trams ${ }^{7}$ were shaking so wildly that the dancing of the letters was counterbalanced.

The situation with regard to scientific magazines in general and computer magazines in particular was similar. One could read the Chip (back than the best computer science magazine in Germany) in the Stadtbibliothek (Central Library of Berlin) but only as Micro Fiche ${ }^{8}$. My friend wrote a letter to the Berliner Zeitung in which he complained about the access restriction for western journals (Höpfner, 1985). He was then invited to talk to the director of the library and the two of us were granted access to the reading room were we could read computer magazines. (Unfortunately, this did not affect other access restrictions, the eight volumes of Nakayamas Karate Perfekt stayed out of reach, you had to have a trainer licence to get them). We later discovered that the library in the ZKI also had the journals we were interested in and

\footnotetext{
${ }^{7}$ The trains must have been of the type TE 59: http://de.wikipedia.org/ wiki/Geschichte_der_Stra\%C3\%9Fenbahn_in_Berlin\#Fahrzeuge

${ }^{8}$ http://en.wikipedia.org/wiki/Microform\#Media. 19.09.2012.
} 
we even could take them home over the weekend (and impress girls with reports about SS20 which were published in Bild der Wissenschaft although the existence of these missiles was denied in the GDR. Some censor must have failed terribly). Later we hacked ourselves into the library system. Being able to manipulate the system, we could have kept the books, journals, and magazines for ever, but, since we are honest people, we returned everything and sent the librarian greetings on International Women's Day from her own account. I guess the journals were much more useful in the library than they would have been in our flats since, by returning them to the library, apart from being honest, we ensured that a lot of other people could read about the SS20s.

So much for my (pre-)scientific life in the GDR. It will serve as background information for the discussion of recent developments. The following subsections deal with prices of books and publications (Section 1.2), restrictions for usage (Section 1.3), and double payment (Section 1.4).

Buying Books and Salaries in the Humanities

As noted by all scientists, the prices for journals and books are constantly increasing. In April 2012, Harvard encouraged its faculty members to publish in Open Access media only and to resign from editorial boards of media that is not Open Access. ${ }^{9}$ Harvard is the richest university in the world but cannot afford the ridiculous amounts of money required to keep their well-stocked library up to date. Imagine what these costs mean for libraries in countries like Poland and Romania. Even institutions in rich countries like Germany cannot afford this since the educational system is notoriously under-financed. I keep getting emails from our library asking which subscriptions can be cancelled. The cuts in education affect positions of technical assistants, research assistants and professors. If we have to choose between people and journal subscriptions, we go for people of course.

But the price problem is not restricted to journal subscriptions, it also affects books. Let's look at some concrete examples. In linguistics, you can find paperback books costing as much as $\$ 175 / 125 €$

\footnotetext{
${ }^{9}$ http://WwW.guardian.co.uk/science/2012/apr/24/harvarduniversity-journal-publishers-prices. 20.09.2012.
} 
(for instance Czepluch, $1996^{10}, 376$ pages, $\$ 0.46 / 0.33 €$ per page) or hardback books costing as much as $\$ 273 / 195 €$ (Pasch et al., $2003^{11}$, 816 pages, $\$ 0.33 / 0.24 €$ per page). The two volumes of the Handbook Syntax by De Gruyter (Jacobs et al., $1993^{12}, 1029$ pages; Jacobs et al., $1995^{13}$, 611 pages) cost $\$ 1006 / 718 €$ in total ( $\$ 0.61 / 0.44 €$ per page). In Saarbrücken, I could not access this book in the CoLi library because it had been stolen ... Another example of a reference work is The Encyclopedia of Language \& Linguistics published by Elsevier. The second edition has 9,000 pages and costs $\$ 6,845 / 4,151 € .{ }^{14}$ This is $\$ 0.76 / 0.46 €$ per page. You could argue that nobody except libraries would want to buy a 9,000 page book, but if we look at the prices for individual papers from this book, it gets worse: a paper with 8 pages costs $\$ 31,50$ ( $\$ 3.94$ per page). ${ }^{15}$

Until now I have been using the German translation of an introduction to logic by Allwood, Anderson, and Dahl (Allwood et al., 1973, 112 pages) for teaching logic to linguists and future German teachers. The book was published by Niemeyer and sold for $9,40 €$ as a paperback. Niemeyer was taken over by De Gruyter and now this book is sold as a reprint for $\$ 126.00 / 89,95 €^{16}$ ( $\$ 1.12 / 0.80 €$ per page).

Books are the tools of scientists. We need them. For instance, a Handbuch (handbook) is something you use frequently. Few people will buy a book for over $100 €$. I buy a lot of books, but my personal limit for a single book is $60 €$. Undergrads will not be able to buy a 112 page text book for $90 €$. They just can't. So, who is supposed to buy these books? Let's have a look at the living conditions in the EU. The salaries for academic staff differ a lot from EU state to EU state. While professors and researchers are relatively well paid in Germany, they get half as much in Greece. According to Wikipedia, a German assistant professor (W1) gets a minimum of 3926,84€. ${ }^{17}$ A research assistant on pay-grade TLV-13 living in West Germany gets a mini-

${ }^{10}$ http : //dx . doi . org/10.1515/9783110955309. 19.09.2012.

${ }^{11}$ http://dx . doi.org/10.1515/9783110201666. 19.09.2012.

12 http : //WWw . degruyter . com/isbn/9783110203417. 19.09.2012.

13 http : / /Www . degruyter . com/isbn/9783110203301. 19.09.2012.

${ }^{14}$ The web page of Elsevier contains several broken links and no prices, so I took the prices from amazon.com/amazon.de.

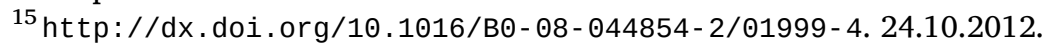

${ }^{16}$ http : //www . degruyter . com/isbn/978-3-11-096350-2. 19.09.2012.

17 http://de.wikipedia.org/wiki/Besoldungsordnung_w. 19.09.2012 
mum of $3186,61 € .{ }^{18}$ While this looks good on paper, the reality in the humanities is different: a lot of researchers have half positions, that is, they get $1593,31 €$. After taxes and social and health insurance they are left with $1105,02 €$. If you compare this with the income of a cleaner who gets $10 €$ per hour, you will be shocked: the cleaner gets $1733 €$ per month. ${ }^{19}$ On the other hand, this is reassuring: you do not have to worry about checking your kids' homework any longer.

Let's think about the things you can do with 1105,02€: the minimum you need to stay alive in Germany is assumed to be $374 €$ (Hartz $4 /$ Sozialhilfe $=$ state welfare). Depending on where you live you might get an additional amount for rent and heating. In Berlin, which is a really cheap city, this is $394 €$. People whose flats are more expensive than this are requested to move to cheaper flats (24.700 households had to reduce their living costs and 1.300 actually were forced to move to new flats in Berlin in $2012^{20}$ ). So the real minimum is in fact $768 €(=374+394)$. For comparison, the money that is spent by the $20 \%$ of the German population that have the lowest income is $483 €$ rather than $374 €$. If you live on the welfare level, you have $337 €$ of your $1105,02 €$ left. If you don't, you probably have nothing left. How many books would you buy per month?

Note also that the German university system differs from the system in the U.S.: while $82 \%$ of the academic staff in the U.S. are professors, with $55 \%$ of all academic staff tenured, only $14 \%$ of the staff are professors in Germany and only $12 \%$ of the academic staff are tenured (Kreckel, 2008). Figure 3 on the following page illustrates. ${ }^{21}$ This leaves us with $86 \%$ research assistants and $74 \%$ of academic

\footnotetext{
${ }^{18}$ http ://oeffentlicher-dienst.info/tv-l/west/. 19.09.2012.

${ }^{19}$ I made the somewhat idealising assumption that the cleaner works 40 hours per week: $40 \times 10 \times 52 / 12$. The payment of cleaners for private flats varies between 7.50 and $15 €$ depending on where you are in Germany. After the switch from BAT-II to the TLV system in 2006 the salary does not contain a locationdependent component any longer. So while a cleaner in Hamburg or Munich gets more than a cleaner in a smaller city, all researchers get the same salary despite huge differences in living costs.

${ }^{20}$ http : //WWw. tagesspiegel. de/berlin/kosten-der - unterkunft werden-neu-geregelt - hartz-iv-empfaenger-duerfen-teurer-wohnen- / 6473264.html. 19.09.2012.

${ }^{21}$ The figure is extracted from http://Www.gew.de/Binaries/ Binary65439/WiKo10_Reinhardt_Kreckel.pdf. 20.09.2012.
} 
Figure 3:

Temporary and permanent positions in different academic systems

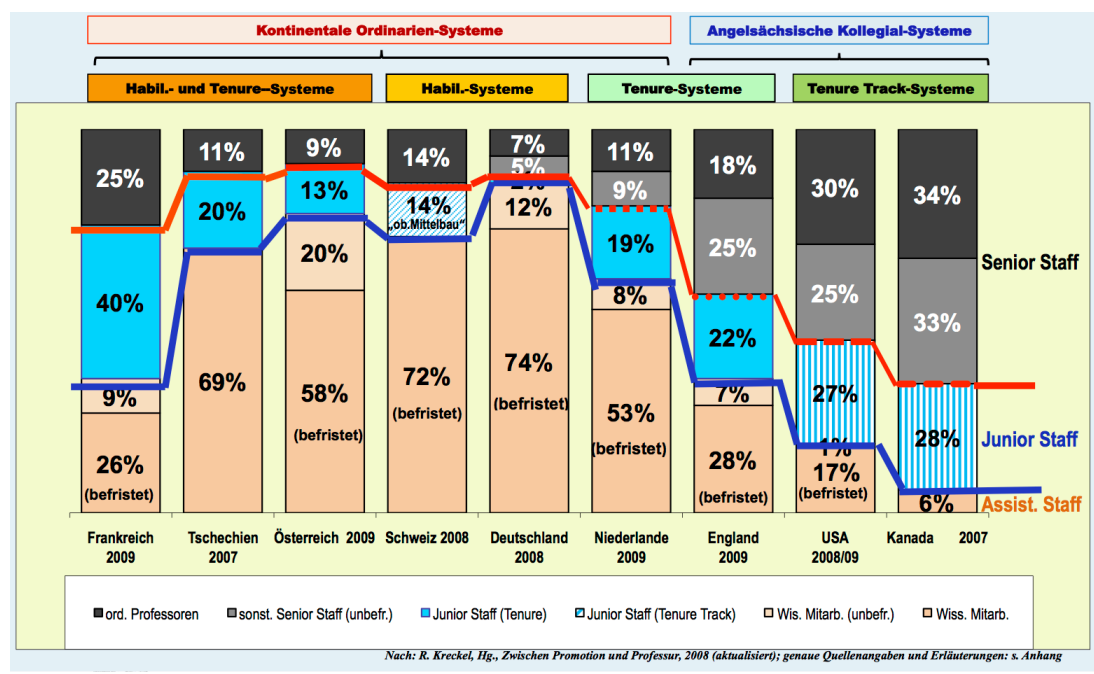

staff in non-permanent positions. This means that $74 \%$ of the scientists working at the universities are constantly looking for new jobs, since they have contracts for two or three years. If they fail to get a new job or cannot move to another town or country for whatever reasons, they have to live on social welfare. Again, the cleaner is in a much better position.

It is almost impossible to get permanent positions at German universities below the professor level nowadays. The reason is that the university system is underfinanced in most federal states and universities use the non-permanent positions to save money: whenever one of the temporary positions becomes vacant, it is blocked from being filled for six months to save money. Most German universities constantly run with just $80 \%$ of their academic posts filled. Now the question: would you buy books if you lived under the constant threat of becoming unemployed? If you have $100 €$ left, you would rather save it for hard times.

Now compare this situation to other countries in the EU. Due to Winfried Lechner's Salary transparency project ${ }^{22}$ we know what an assistant professor earns in Greece: $1,361 €$ after taxes. From this salary you have to subtract at least $150 €$ per person for private health insurance. What is left is comparable to a research assistant in Germany

\footnotetext{
${ }^{22}$ http://users.uoa.gr/ wlechner/. 19.09.2012.
} 
on a half position. A research assistant in Greece earns $1,291 €$ after taxes. In comparison to 2008, salaries have been cut by over $26 \%$ (up to $32,2 \%$ for full professors). The living costs in Greece are lower in general, but if you live in Athens, not much is left for buying books. ${ }^{23}$

We have seen some examples from the EU and I leave it to the reader to imagine incomes and living costs of researchers living in other, less wealthy countries.

\section{Accessing and Using Books}

The preceding section discussed the impossibility of buying books as an individual scholar, but maybe we do not need to buy books. Maybe Kuczynski (1983) was right in letting his great-grandson ask why he afforded the luxury of a big private library. The alternative is, of course, public libraries. But, again, we have to deal with underfinanced educational and research systems. Some countries have few libraries and if finances are restricted, how would you convince the librarian to buy books about Pirahã? There is no immediately visible economic use of such linguistic research (not even in computational linguistics, since there are just a few speakers of Pirahã and they do not have iPhones).

Apart from this, there is the problem of access restrictions that may be imposed in certain countries. You cannot predict what will be banned for what reasons. I was shocked to find The Diary of a Young Girl - Anne Frank, The Adventures of Huckleberry Finn, and Alice's Adventures in Wonderland, Harry Potter and the Philosopher's Stone ${ }^{24}$ on the list of banned books maintained at http://Www. banned-books. org.uk/. I lived in a state where Animal Farm (also on this list) was banned: I know of people who got this novel page by page in letters from their relatives in the West. And, as mentioned earlier, in the 50's and 60's you could go to prison for 25 years if you were caught with

\footnotetext{
${ }^{23}$ According to user information at ht $\mathrm{tp}$ : //WwW. numbeo. com/cost - of - liv ing/compare_cities. jsp?country1=Germany\&country2=Greece\&city $1=$ Berlin\&city2=Athens the living costs in Athens including rent are $12,36 \%$ higher then the living costs in Berlin.

${ }^{24}$ Banned and burned in some states of the U.S. for promoting witchcraft.See http://en.wikipedia.org/wiki/Religious_debates_over_ the_Harry_Potter_series for more information on the debate. I guess, depending on the country, Pippi Longstocking should also be banned. Either because the main character has red hair or because Pippi is much stronger than the boys.
} 
the wrong books. As should be clear from what I just said: the problem was to get the books. All possible routes into the country were controlled: letters, parcels, the borders. The internet did not exist back then in the Eastern Block countries. ${ }^{25}$ But this has changed. People in many countries have ways to connect to the outside. The access to information can take place through ssh tunnels, which will be difficult to decrypt for authorities. The question whether a book may be imported or not will not arise. Whether there will be any conflicts with state authorities depends solely on the diplomacy of those who are accessing the files.

We have seen that there can be economical or political reasons for books being inaccessible, but even for those researchers who have access to books and who can afford to buy them, the situation is unsatisfactory since they cannot work with them properly because buying the book usually does not include the right to access and store an electronic version of the work. Those who need the book in electronic form (for searching or accessing it in places where you cannot take heavy books to) have to scan the book and illegally store the file.

Writing books, reviewing books for publishers, and copying them afterwards takes a lot of time. This time is usually paid for by state institutions or funding agencies. The publishers do not pay for it. On the contrary, some even require money from the authors to keep the book prices low (depending on the number of copies printed, this can be $1000 €)$.

I want to give two more concrete examples: I spent one month reviewing a book for Benjamins. You may check the sources mentioned above to find out what this actually cost German taxpayers. I am not

\footnotetext{
${ }^{25}$ We had Unix systems at the Humboldt University and they had a network, but this network was not connected to the outside world. It was nevertheless useful: we had a disk quota of $1 \mathrm{MB}$. One could not log out of the machine if one used more than $1 \mathrm{MB}$. The trick was to pack one's files into an archive and send this archive to oneself per email. At the next login the archive was extracted from the mail folder.

It was in the news today (25.09.2012) that the Islamic Republic of Iran will have such an inhouse email system soon. I hope that computer scientists, computational linguists, and others will find ways of using it ...
} 
complaining here about the work. I enjoyed it very much. I would have read the book anyway since I found the topic interesting. But the problem is that the publisher now has a product that is better than it would have been without my work. The publisher will sell more copies and will make more money out of it. If I had not asked for it, I would not even have gotten a sample copy of the book. The book costs $\$ 150 / 100 €$ now and is way too expensive ( $\$ 0.45 / 0.30 €$ per page).

Another example is the books that appear in the legendary HSK series of De Gruyter. Authors do not even get a copy of their book. They get the right to download 10 journal articles (which would cost $400 €$ if you ever paid for them) and they can buy the book with a $30 \%$ discount. As will be discussed in the next section, the distribution costs for books (distributor, bookshop) make up $55 \%$ of the total cost. Since these costs are saved when authors get their copies directly, De Gruyter takes the normal margin plus an additional margin of $25 \%$ from their authors.

The final example shows that we even have cases of triple payment: Christiane Fellbaum reported a case in which a publisher wanted to charge her (personally) since she wanted to reuse a figure with another publisher. So we have to buy our own products in order to give them to another publisher from which we can then buy it again.

So, we do a lot of work that is paid by the tax payer or not at all and we pay again when we buy our products.

2

WHO DOES WHAT

AND WHY IS IT SO EXPENSIVE?

As we saw in the previous section, book prices and journal prices are just too high. But why is this so? Who gets all this money? Depending on the contract with the author, the costs of a book consists of the following:

1. work done by the author (paid by the research institution or by nobody)

2. production costs (editorial process, employees of the publisher, design of cover, ISBN number, ${ }^{26}$ paper, printing)

${ }^{26}$ The costs of ISBN numbers vary from country to country. While they are free in Canada, ten ISBN-A cost $100 €$ and 500 cost 1,500€ in Germany. 
3. storage and maintenance cost for infrastructure for electronic publications

4. advertising costs

5. publisher's profit margin

6. royalties for the author

7. storage of the books (Zwischenlager)

8. distribution of the book by a main distributor

9. distribution of the book by a bookshop

10. added value tax (depends on the country/state ${ }^{27}$ )

Sadly enough, items 7-9 can be up to $55 \%$ of the total book price. As for the author's royalties: we saw in Section 1.4 that authors often pay publishers in order to keep the book price low. When this is the case, they (probably) do not get any royalties. So we are left with the production costs and the margin of the publisher. Here it really depends on the publisher. Some publishers (as, for instance, De Gruyter) do a really excellent job and typeset the whole manuscript so that you end up with really beautifully typeset books. Others, like Niemeyer, didn't do much. They accept submissions in Microsoft Word ${ }^{28,29}$ and I even remember photocopied typewriter manuscripts that had a page 129a between the pages 129 and 130. So the efforts spent on typesetting vary but most publishers do proofreading, check the margins, paragraphs, watch out for widows and orphans, and so on. This involves human labour and hence is expensive.

\footnotetext{
${ }^{27}$ In Germany the added value tax for food and books is $7 \%$.

${ }^{28}$ Word is not a typesetting program. It often gets the kerning wrong and there were times when it hyphenated German aber as a-ber which is correct according to the spelling rules (Duden, 1996, p. 61), but is typographical nonsense.

${ }^{29}$ My favourite story about Microsoft Word is about a paper that was published by Microsoft research (Gamon and Reutter, 1997). I tried to print it (back in 1998) and it caused a paper jam. While preparing this paper, I had a look at the PostScript file again and the PostScript to PDF converter that comes with Mac OS failed on it. Closer inspection of the file revealed that it included printer specific commands.

While editing the HPSG proceedings this year, I almost went nuts since the AVMs in PDF files produced by Microsoft Word caused problems when the PDF was created under Windows. They looked correct under Windows and some nonWindows viewers but were broken on others.
}

So much for standards and an open world with free communication. 
The profit margins are generally unknown but for some large publishers the numbers are available: Elsevier had a turnover of $£ 2,058 \mathrm{M}$ and adjusted operating profit of $£ 768 \mathrm{M}$ in $2011 .{ }^{30}$ Springer Science + Business Media S.A. had a turnover of $875 \mathrm{M} €$ and pre-tax profit of $313,3 \mathrm{M} €$. This is a margin of $37.17 \%$ for Elsevier and of $35.80 \%$ for Springer. This should be compared with Siemens $(8.6 \%)$ and Daimler (5.6\%). I clearly remember the outcry that went through the German press when Josef Ackermann, back then the CEO of the German Bank, announced that the German Bank aims for a $25 \%$ of return on equity. Return of equity is different from pre-tax profit and a more realistic goal for a bank, but here we are: our beloved publishers make even ten percent more profit before taxes than what was thought to be Turbokapitalismus ${ }^{31}$ ('turbo capitalism') in the German Bank discussion.

To conclude this subsection, what we get from good publishers is the following:

1. a brand corresponding to a well-maintained profile

2. marketing (display at conferences, leaflets, web pages, mailings, library contact)

3. support in getting the permissions for reprinting figures (only relevant in some subdisciplines like neurolinguistics)

4. storage and maintenance of electronic publications

5. typesetting

6. proofreading

The publisher also takes care of organisation of content that may affect the market success of a book. We do not necessarily like this as authors ...

The costs in 1-6 are fixed costs that do not depend on the number of copies that are printed. If the book production costs $2000 €$ and you sell 500 copies, the production costs per book are $4 €$. If you sell 100 copies, the production costs are $20 €$ per book.

\footnotetext{
${ }^{30}$ Reed Elsevier Annual Reports and Financial Statements 2011, p.9. Availible: http://reporting.reedelsevier.com/staticreports/Reed_AR_ 2011.pdf. 24.10.2012

${ }^{31}$ http://de.wikipedia.org/wiki/Turbokapitalismus. 24.10.2012.
} 
The result is that publishers are not interested in publishing books with a limited audience (on Danish or formalisation of linguistic theories) or they are interested and charge enormous amounts of money for the printed book.

The solution to these problems is Open Access publishing. Publications that are accepted after a selective reviewing process are stored on central storage and archiving servers, for instance those that are provided by university libraries. For books it is still important to have the printed version, so here the solution is Open Access in combination with print on demand services. The copyright is granted by the Creative Commons CC BY ${ }^{32}$, which allows the work to be printed and figures to be reused, provided the original work is cited. The translation rights remain with the author. The authors can additionally put a PDF file of their work on their web page and for those of us who prefer printed books, printed copies will be available on demand. In order to get some idea about prices, we can look at the Amazon daughter Create Space: as of 20.09.2012 Create Space publishes a $15 \times 23 \mathrm{~cm}$ book $(6 " \times 9 ")$ with 450 pages for $\$ 10.5=£ 8.7=$ $10 €(\$ 0.023 / 0.022 €$ per page, cheaper by a factor of $20-50$ !). This includes a free ISBN number and the number of printed copies is irrelevant for the price calculation. For a price calculator see https: //WWW. createspace.com/Products/Book/.

Note that the publication as a printed book is not obligatory. The main publication format is the electronic publication. Those who want to stay away from large companies do not have to print and distribute their book via Amazon. There are several other print on demand services that can be connected to the publication on a web page.

In the next section I address the challenges for and advantages of publishing this way. Some of these challenges have already been addressed by College Publications, which is a publisher run by academics for academics. College Publications was founded by Dov Gabbay and Jane Spurr and has interesting series in Logic, Linguistics, and Computation. They also guarantee low book prices $(\$ 15-25$ per an average

\footnotetext{
${ }^{32}$ http://creativecommons. org/licenses/by/2.๑/. 27.09.2012.
} 
300-page book) and allow authors to put their book at their web page once sales have achieved profitability. ${ }^{33}$ As will become clear in the next section, we want to take the whole approach a step further.

4

\section{GHALLENGES AND ADVANTAGES}

If we publish without traditional publishing houses, we have the following challenges:

- quality control

- content

- proofreading

- typesetting

- marketing

- long-term accessibility of documents

We are currently in the process of setting up Open Access Platform for linguistics books (OALI, http://hpsg.fu-berlin.de/OALI/) and I will therefore focus on books in the following subsections.

4.1

Quality Control

Publishing houses differ as far as quality control is concerned. Some ask researchers to review book manuscripts, some rely on the reputation of the respective authors and publish whatever they submit. The reviewing process could be organised by the scientific community without the mediation of publishing houses (we do this for conferences anyway). The duty of a reviewer would be to comment on the manuscript and also to point out typos (part of proofreading). Typos could be marked during reading and communicated to the authors via a PDF (either the marked PDF of the submission or a scanned paper version). The names of the reviewers can be published on the book. Publishing the reviewers' names is an old suggestion by Geoff Pullum: Pullum (1984) suggested in his column in NLLT that reviewers of journal articles should be named in the article since this ensures that they take reviewing seriously and also gives credit to their work since more often than not the reviewed piece profits from the comments. We can take Pullum's ideas even further. We can build a web of trust.

\footnotetext{
${ }^{33}$ http: //WwW. collegepublications. co. uk/about/. 24.09.2012.
} 
We can set up reviewing systems that keep the original submission around and add the review. After a revision there could be another review and another revision. Readers can comment and other readers can vote on books and comments. The versioning is basically what we have in Wikipedia and the rating system is practised very successfully on http://stackexchange. com/. stackexchange.com has a list of rated questions and answers and you get credits for asking and answering questions. So you can see who is an experienced user of this system. There are certain thresholds for user privileges that are assigned automatically by the system. It may sound silly at first, but it is psychology (Radoff, 2011): doing reviews with such a system is much more fun than doing it just for the love of it. We could give points for reviewers who are fast (you will also have the information about the time the reviewing took, if we keep versions of documents and reviews publicly available). Of course not all reviewers may want this, but we could give points or badges for transparency. So everybody has the option of making her or his review publicly available, but does not have to. There is also the problem of rejected manuscripts. The reviewing work should be credited somehow by the system although the identity of the reviewer does not have to be revealed.

In the case of manuscripts of bad quality, that is, manuscripts that would require a lot of work on the reviewer's side, it could be the case that nobody is willing to review the manuscript. This can be either accepted by the author as a rejection or the author could increase the motivation for reviewing by setting a 'bounty'. Bounties can be set on systems like stackexchange to increase the priority of a question. Those who answer the question will get a bigger number of credit points and the person who asked the question has to 'pay' with some of his or her credit points. If the manuscript has some good ideas in it, reviewers eventually will be willing to invest a lot of time in a manuscript. The extreme version of the 'bounty' idea is of course co-authorship.

Reviewing will normally be done by researchers with a $\mathrm{PhD}$, but the envisioned system allows something like a customer's review, which can be written by everyone. Readers can comment on the books they read and will get points for this. Others can judge the reviews as useful or adequate and this could result in further credits assigned to the author of the review. In that way, talented researchers below $\mathrm{PhD}$ level can build a reputation. 
Of course, setting up all this in a way that is accepted by the community and that is not vulnerable to manipulation is a non-trivial task. If you are interested in helping to develop and extend software in the directions indicated above, please register at https://lists. fu-berlin.de/listinfo/OALI - developers. Issues related to Open Access in Linguistics and the development of the software will be discussed in Frank Richter's blog at http://www. frank-m-richter. de/freescienceblog/.

Another interesting aspect in this scenario is that one can use it to bridge the huge gaps in linguistics that some call a crisis of the subject. I think that from a bird's eye view ${ }^{34}$ frameworks are not too different (Müller, 2010, Submitted) and maybe a reviewing system that motivates people to look at each other's work critically can bridge the gaps and in the end will result in improved quality in all areas of linguistics.

Since books are printed on demand, there will not be 100 or more copies that have to be sold until one gets to the next edition. This allows for the correction of typos and errors. A version chaos can be prevented by introducing time limits for resubmission.

The big advantage of this publishing model over the traditional one is its flexibility and speed. One could imagine settings in which the author sets the price of a printed book so that it includes royalties for the author. In such a setting we could request that the author pays the reviewer and maybe even an overhead for the organisation. This could be a fixed price to reduce management overheads or a certain percentage of the book price. The authors paying the reviewers seems to be a conflict of interest, but the reviewers are interested in the commercial success of the book and will do everything to improve it and, in addition, their name is published with the book, so they will do whatever they can to ensure quality.

Publishing houses live from their brand names. When they go bankrupt other publishers buy them, just to get established journals and book series (Mouton, Niemeyer, K. G. Saur Verlag $\rightarrow$ De Gruyter; Kluwer, Springer $\rightarrow$ Springer Science + Business Media, ...). What we need for books is a brand. We are seeking to establish a brand name that is associated with high quality books. The initiative at the FU is

\footnotetext{
${ }^{34}$ Some birds can fly as high as $11,300 \mathrm{~m}$.
} 
therefore looking for linguists from all branches of linguistics who are willing to participate in the reviewing process and who want to take part in building a brand with a good reputation. The area of expertise of the first supporters of the original proposal is in data-informed theoretical linguistics but, of course, book series in other research areas are possible and welcome.

What we are doing is similar to what publishing houses do. In order to keep the task manageable, we need software for load distribution (the gamification idea mentioned above) and we need subareas of responsibility, that is, series that are run by a few editors that are acknowledged experts in their field. Publishing houses usually have an advisory board that installs such series. We need a board of experts, too. This will be set up in the near future.

Typesetting

While you have full control over your product if you publish without a traditional publisher, the disadvantage of this alternative way is that you have full control over your product. This means that you have to do the proofreading and the typesetting alone. ${ }^{35}$ Cambridge University Press estimates the costs for typesetting a 400-page book at $£ 1000$. If authors are willing to invest the equivalent of $£ 1000$ in formatting the text themselves by learning how to use $\mathrm{LAT}_{\mathrm{E}} \mathrm{X}$, the nonprofit publisher saves this money and the readers will enjoy cheaper books. One good thing about Open Access publications is that they can be Open Source too. I gave away the source of my HPSG textbook (Müller, 2008), but, while working on the Persian book (Müller et al., In Preparation), I discovered $\mathrm{X}_{\mathrm{H}} \mathrm{L}_{\mathrm{E}} \mathrm{X}$ and also switched to a new tree drawing package. Once this book is finished, I will make the source code available, so that everybody who is interested can learn how certain elements can be typeset. The source code of this article is available at http://hpsg. fu-berlin.de/ stefan/Pub/oa-jlm.html.

Frank Richter and Chris Culy are currently working on a translation of $\mathrm{LT}_{\mathrm{E}} \mathrm{X}$ into e-book formats that would also make it possible to publish typographically complex books including glossed and heav-

\footnotetext{
${ }^{35}$ Many of us actually prefer doing the typesetting by ourselves instead of having professional typesetters but non-linguists messing around with the symbols. See for instance Ivan Sag's post on the HPSG mailing list: http://hpsg . stanford.edu/hpsg-1/1997/0062.html. I typeset all of my books myself.
} 
ily crossreferenced examples, syntactic trees, OT tableaux, and feature structures.

At the OALI kickoff meeting it was decided that Microsoft Word submissions should be an option. So it is like with the Journal of Language Modelling: Microsoft Word possible, but $\mathrm{LT}_{\mathrm{E}} \mathrm{X}$ strongly preferred. Editing and translating Microsoft Word files is labour and hence cost intensive. We have to find ways to pay this work, for instance by external funding from foundations, research organisations, or donors. Of course authors who submit manuscripts that cause a lot of work could also donate or find local people who do the $\mathrm{L}_{\mathrm{E}} \mathrm{X}$ conversion for them, which may be a lot cheaper than doing this in countries like Germany.

If we have more donations than are needed for typesetting and other running costs, we could subsidise the printing and even offer books below the print on demand costs.

\section{Marketing}

What we cannot do is travel around with a truck of books and present them at conferences. But we can establish a brand and we can promote it at conferences. Actually during show time at the end of our talks. Since the books are accessible, search engines will find them. Since students and researchers from economically weak countries will be able to access them, there will be a bigger audience for the book.

Publishers send books to multipliers, known researchers in the field that may be interested in the book, use it, cite it, and tell others about it. The names of the multipliers are usually provided by the authors. Furthermore, reference copies are sent to certain libraries (for instance the German National Library for books that are published in Germany). In addition, books are sent to journals for reviewing. We will put together lists of journals and help the authors send the books to them.

The most important site for promotion of work in linguistics is the Linguist List. It has over 25.000 readers. Non-profit work can be announced there without any fees.

In addition to the Linguist List publications can be advertised on www. academia.edu. As of 06.11.2012, there are 5,704 researchers that have linguistics as their research interest and 11,633 with the research interest languages and linguistics. When you upload or link papers on academia.edu, you can tag them with respect to certain 
research interests. Everybody who has research interests that correspond to the tags will see your new upload. This results in much more targeted distribution of information. For instance, there are 1361 researchers with Natural Language Processing, 972 researchers with Computational Linguistics, 916 researchers in Syntax, and 145 researchers with Persian Language among their main research interest. If you tag your paper accordingly, the news about this paper will reach these researchers directly. We have also installed the group Open Access Books in Linguistics in which freely accessible books can be announced.

4.4

Long Term Accessibility of Documents

The books will be printed and copies will be sent to and archived by reference libraries. Long term accessibility is guaranteed for the electronic publications: (German) university libraries have storage systems that can be used for long term storage. These document servers are connected to international catalogues, which guarantees visibility of the documents. The documents get a Digital Object Identifier (DOI) and, hence, servers going out of business, changing URLs and so on do not cause problems.

4.5 Advantages

In the previous subsection we looked at challenges for the new approach and concluded that they are manageable. This brief section highlights some of the advantages. They are:

- Speed

- Version control

- Visibility

- Connection to the primary data and software

The new way of publishing allows scenarios that differ from what we know so far. Authors can make drafts of their book available to the community as soon as there is something to show. Some authors do this and did this in the past, but publishers frowned upon this and some refused to publish books that were in the net before submission. The initial submission could be stored together with reviews and with improved versions of the document (Wikipedia-like). This guarantees that the earliest moment in which a certain idea was present is doc- 
umented. It also opens up new possibilities of quality improvement. Readers alert authors of mistakes and typos in a phase after acceptance and before finalisation.

The documents are accessible by all search engines not just by those that are run by companies that happen to have a contract with the publisher.

The publications can be stored together with primary data and software. (Some) publishers are setting up this infrastructure now and some authors have already done this on their own, but there are entirely new possibilities as demonstrated by the projects of Enhanced Digital Publication ${ }^{36}$. The Enhanced Digital Science project looked at various disciplines, also including linguistics. One project developed a dictionary for Berber that includes background information like pictures and articles from the press. Other useful combination of sources can easily be imagined for linguistics. For instance, one could connect a text to corpora and subcorpora that play a role in an analysis, one could include interactive example trees that can be manipulated and modified by the reader since they are connected to online demos of linguistic software. Usually fully worked out linguistic analyses are highly complex. It is the task of the author to simplify the analysis and highlight the most important aspects. However, in some situations the reader wants more or it is not obvious how several partial descriptions in a paper have to be fused into a coherent picture. Having a tree that contains all the details of an analysis but initially displays only the information that was marked as relevant by the author is extremely useful here.

5

OPEN AGGESS

AND TRADITIONAL PUBLISHERS

You may wonder why we should go through this organisational nightmare. Aren't there publishers already who publish Open Access, both journals and books? Yes, there are. But, of course, most publishers are profit-orientated companies. Let's look at some examples.

\footnotetext{
${ }^{36}$ http://Www.surf.nl/en/themas/openonderzoek/ verrijktepublicaties/Pages/default . aspx. 08.11.2012.
} 
Elsevier offers the option to publish open access, but charges the authors. Their web page is not transparent, but http://www. sherpa. ac.uk/romeo/PaidOA.html lists publishers with an OA option, and according to this page, Elsevier charges $\$ 3000$ or $\$ 5000$ for one article, depending on the journal. During a panel discussion on Open Access I asked the Elsevier representative in the panel, Angelika Lex, about the $\$ 5000$ that Elsevier takes for a publication in Cell. ${ }^{37} \mathrm{I}$ asked about how Elsevier justifies a fee that corresponds to a month's salary of a German professor. The reply was that there are general costs for storage and maintenance and the editorial process and that Cell is a very prestigious journal with four articles out of one hundred submissions actually published. So, what Biologists really pay for is the brand. A brand that they helped to establish and that they are helping to maintain by doing the quality control.

Springer offers a publishing model in which all rights remain with the author. ${ }^{38}$ However, the authors or their institutions have to pay $\$ 3000 / 2000 €$ (excl VAT).

Finally, let's look at De Gruyter. At the beginning of 2012 De Gruyter bought Versita and is now the world's third largest player in the Open Access branch. De Gruyter takes $\$ 2,450 / 1,750 €$ from authors for access to their Open Library. ${ }^{39}$ Versita does not charge any money for publishing books right now, but this is limited to the first 200 books. ${ }^{40}$ The prices of printed books will be the same as the prices of De Gruyter (p. c. Agata Morka, Product Manager, Books, 04.09.2012). Versita has interesting job offers for $\mathrm{PhD}$ students or postdocs: you can work with them as an Assistant Editor. The job is not paid. In exchange you get a unique opportunity to acquire experience in

\footnotetext{
${ }^{37}$ http://www.ibi.hu-berlin.de/aktuelles/veranstaltungen/open_ access/podiumsdiskussion provides an audio recording of this event. The answer of Angelika Lex starts at 1:55:51.

${ }^{38}$ http : //WWW. springer. com/open+access/open+choice?SGWID= ๑- 4๑359- - - ๑- ๑. 22.09.2012.

${ }^{39}$ http : //Www. degruyter.com/dg/page/16/de-gruyter-open-library. 22.09.2012

${ }^{40}$ http://versita.com/Book_Author/FAQ. 22.09.2012.
} 
and understanding of professional scientific publishing. ${ }^{41}$ That is the way companies work nowadays. They get your work, you get the experience. A lot of young journalists, architects, landscapers, you name it, work that way. If you want to know where this leads to, check Section 1.2. If you want to have contact to authors, participate in professional peer reviewing, and be Teil einer Jugendbewegung, you can also work with us. We pay at least the same salary and are much cooler!

Publishing OA this way solves the problem for some of us: the readers. It does not solve the problem for the writers. Remember: we are working in underfinanced academic systems. $\$ 3000 / 2000 €+19 \%$ taxes $=\mathrm{a}$ lot of money. It is two months' salary for a researcher in some of the European countries. If a German university publishes 25 articles per year that way, it could use this money to pay a programmer working on software for Open Access for a year in Germany $(2000 €+19 \%$ $\times 25=59.500 €$ and $58.800 €$ is the amount for a full position including overheads)! In fact, the German Research Foundation (DFG) pays one million Euro per year to support this form of Open Access. I think this is nice for the researchers that are supported since their visibility is increased, but it does not solve the actual problem. As was reported in Section 2, 35\% of the money that we or the taxpayers pay will be the profit of the publishers. So, rather than financing the profit of publishing houses, the DFG and universities should finance alternative structures that do not work profit-orientated.

Finally, I want to remind the reader about economically weak countries: how should they finance such publication costs? By shifting the system from reader pays to author pays, we systematically exclude whole continents from contributing to scientific progress. This is terrible for all sciences but maybe the biggest loss for linguistics.

So, we can conclude that this form of OA publishing is not an option.

\footnotetext{
${ }^{41}$ http ://linguisticsnotes . wordpress . com/2012/02/20/invitationfor - assistant - editor - open-access - books - in-linguistics/. 22.09.2012.
} 
A frequently asked question is whether an Open Access publication will help the author in getting tenure, whether the publication will count for promotion or in an evaluation of the research institution as they are common in Great Britain, for instance. In Great Britain the SENSE Research School uses a list of publishers that are ranked according to their quality for the evaluation of academic institutions. ${ }^{42}$ According to this list, you get one of four possible credit points for publishing a book chapter with Peter Lang, you get zero points for publishing with Mouton De Gruyter or the Akademie Verlag. This does not correspond in any way to the importance of these publishers. While I would subtract a point from every department that publishes with Peter Lang, De Gruyter cannot be valued high enough. They run established series like Linguistische Arbeiten (bought from Niemeyer) and the legendary HSK series. The Akademie Verlag has the series studia grammatica, which was established in the 60's and published some of the most important books in German linguistics (Bierwisch, 1963; Kunze, 1975, 1991; Heidolph, Fläming, and Motsch, 1981; Wurzel, 1984; Stiebels, 1996). I personally own 10 books of studia grammatica, 19 books from the Linguistische Arbeiten and 10 other volumes of the various De Gruyter publishing houses, including the German version of Le cours de linguistique générale by Saussure and Syntactic Structures and Lectures on Government and Binding by Chomsky. I do not own any books from Peter Lang. What this is supposed to show is that the way in which research is evaluated should be changed. ${ }^{43}$ In the meantime, however, OA initiatives have to be very careful not to get into a bad category in any of the lists that are used for evaluations.

Turning to the question of getting tenure, I guess that whether one gets tenure depends on the attitude of the tenure committee towards Open Access publishing. The list of the supporters of Open Access Linguistics Books ${ }^{44}$ includes prominent names like Anne Abeillé, Steven Abney, Artemis Alexiadou, Johan Bos, Peter Culicover, Gisbert Fanselow, Anette Frank, Christiane Fellbaum, Charles Fillmore,

${ }^{42}$ http: //WwW . sense $\cdot \mathrm{nl} / \mathrm{uploads}$ ?\&func=download\&fileId=855. 14.10.2012.

${ }^{43}$ I do not suggest an evaluation scheme where the credits correspond to the number of books of a certain publisher on my bookshelf.

${ }^{44}$ http: //hpsg. fu-berlin. de/OALI/\#supporters. 27.09.2012. 
Edward Gibson, Adele Goldberg, Martin Haspelmath, Hubert Haider, Ron Kaplan, Ewan Klein, Wolfgang Klein, Manfred Krifka, Gereon Müller, Steven Pinker, Friedemann Pulvermüller, Marga Reis, Ivan Sag, Stuart Shieber, Mark Steedman, Luc Steels, Tom Wasow, Dieter Wunderlich, and Annie Zaenen (to name just those with the highest h-index, but not sorted according to the h-index). ${ }^{45}$ So, I believe that this will influence a change towards Open Access. However, those younger researchers who are insecure should go the traditional way for now, but if we manage to make the reviewing process transparent, a book publication in OALI may count more than other book publications one day. Open Access journals are already quite successful in other fields. For instance, two of the journals run by the Max Planck Society are leading their field (Living Reviews in Relativity, impact factor 17.462 best journal in "Physics, Particles \& Fields" and Living Reviews in Solar Physics, impact factor 12.500, third in "Astronomy \& Astrophysics"). ${ }^{46}$

Coming back to the tenure question: whether Open Access publications make sense for an individual career also depends on the university system. As was discussed in Section 1.2, European university systems are organised very differently from the Anglo-Saxon system. While $82 \%$ of the staff are independent researchers (professors) in the U.S., it is the other way round in Germany: $86 \%$ work as depen-

\footnotetext{
${ }^{45}$ I am fully aware of the fact that the h-index is a problematic criterion when it comes to the evaluation of scientists and the German Research Foundation explicitly bans the h-index (Deutsche Forschungsgemeinschaft, 2010), but, due to some traumatic experiences at the Freie Universität, the h-index (and research evaluation in general) became one of my hobbies, and I use this index here as a measurement of citations and hence visibility.

I used Google Scholar, since the Thomson \& Reuters database is unusable for linguistics. For example, Chomsky has an h-index of 16 there, whereas Friedemann Pulvermüller, working in neurolinguistics, has an h-index of 45. Chomsky's h-index in Scholarometer is 95! It's the books that make the difference! Scholarometer (formerly known as Tenurometer) should not be used in evaluations though, since they have problems with the Google API and omit citations that are marked as [citation]. This can result in up to $50 \%$ of citations missing in search results.

For a discussion of more general problems with the hand made evaluations made by Thomson \& Reuters see Rossner et al., 2007.

${ }^{46}$ http : //WWW.mpg . de/5888876/impact_open_access. 20.09.2012.
} 
dent researchers. $74 \%$ of the researchers are working on temporary positions. So, it is very difficult to get a permanent position and the most important thing is to stay in the system. The average age for getting tenure in Germany is 41 years. If you manage to stay in the system long enough and you keep publishing, you will get a permanent position (professorship) one day. ${ }^{47}$ In such a system the situation is slightly different: if you publish a good book that is read a lot, the opinion of search committees will not so much depend on the question of whether the book was published Open Access or by Peter Lang, rather the impact will be the most important thing. If everybody in the search committee knows the book and if it is cited a lot, it does not matter how it was published. And the chances are high that a book gets more popular and is cited more often if it is freely available (Lawrence, 2001; Harnad and Brody, 2004; Harnad et al., 2008).

\section{DISCLAIMER}

The question of the distribution of knowledge is independent of the question of how novels, movies, and music should be distributed. I do not share radical views about copyright. I think that artists should be paid and I have paid for all my music, either for the CD or for the downloads. Yes, I also payed for Deichkind's title Illegale Fans. I even bought the whole album! (see Figure 4 on the next page) ${ }^{48}$ In particular, I do not share the view of the Pirate Parties that have developed mainly in Europe but are also present in Canada and the U. S. ${ }^{49}$ This view is also reflected in Anatol Stefanowitsch's Open Letter to the

\footnotetext{
${ }^{47}$ Thanks to Tibor Kiss, who pointed this out to me when I was frustrated.

${ }^{48}$ Clearly, there are things to complain about in this business as well. I remember a time in the 90's were CD prices were doubled from about 20 DM (roughly $10 €$ ) to almost $40 \mathrm{DM}$. For reasons I do not understand, the prices for AC/DC disks stayed constant. The titles that fit the description in Section 1.2 are It's a long way to the top, if you wanna rock'n'roll and Ain't no fun waiting round to be a millionaire from Dirty Deeds Done Dirt Cheap. Go and buy this record!

${ }^{49}$ The Pirate Party is represented at the government level in many German states (up to $8,9 \%$ of the votes). One of their main political goals is the legalisation of file sharing and the prohibition of digital rights management systems. While I share their views on participation and transparency and also some of the suggestions to revise copyright regulations, I do not agree on file sharing of content without the agreement of the creators.
} 


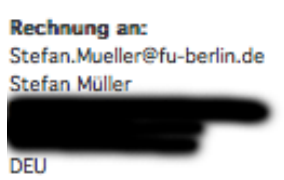

Bestellnummer: MGVMZM69VF

Belegdatum: 28.02.12

Bestellung gesamt: $9,99 €$

Rechnung an: Visa
Figure 4:

Receipt for the Deichkind album including Illegale Fans

\begin{tabular}{lllr}
\hline Artikel & Interpret & Art & $\begin{array}{r}\text { Preis pro } \\
\text { Stūck }\end{array}$ \\
\hline $\begin{array}{l}\text { Befehl von ganz unten (Bonus Version) } \\
\text { Eine Rezension schreiben }\end{array}$ & Ein Problem melden & Deichkind & Playlist \\
\hline
\end{tabular}

Content Industry (Stefanowitsch, 2012) and some of the comments in his blog. Stefanowitsch suggested that artists can produce art in their spare time and that they should provide it for free and not charge others money. Here is my reaction to this view: of course, one can be an artist in one's spare time, but think of complex arrangements in music: do you believe that the Beatles or Pink Floyd could have composed their music in their spare time? Do you think that Frank Zappa should have worked as a car manufacturer or as a waiter? Or Jello Biafra as a postman? ${ }^{50}$ Think about it: making music is not just putting a band together and playing some tunes in Joe's garage. If you play with orchestras, this takes a lot of time. Recording a song in the studio takes a lot of time. A lot of people are involved and have to be paid. How would you combine going on tour with your everyday working life? Do you think you could create photographs of the quality of Ansel Adam's pictures in your spare time? This is not possible. Believe me, I tried! ${ }^{51}$ Anatol, if you write blogs in your spare time and provide content for free, this is not your spare time! You are building a reputation (a good one, I think, if we ignore the copyright issues for a moment). This reputation adds to your value and gets you better and better paid

${ }^{50}$ Cf. Stealing People's Mail from Fresh Fruit For Rotting Vegetables, Dead Kennedys, Decay Music, 1980.

${ }^{51}$ For some pictures of linguists licenced under Creative Commons (BY-NCND) see LingPhot at http://hpsg.fu-berlin.de/ stefan/Bilder/. 
jobs. Compare this with the life of a graphic designer: I used to live in an area where you can meet lots of them, they have to sublet parts of their flats to be able to survive and their living standard is comparable to the standard you have when you are employed in the humanities or below (I am talking about graphic designers with a university degree). You as a professional scientist should know that you have to use all the time you can for your research to ensure quality. If other tasks (like funny search committees that keep you busy for years) take that time, quality suffers. This is the same in art and design. Do you think a cup is designed in spare time? This is a process that takes over a year. Not everybody can do this. You can't. I can't. Do you want to have nice products? Do you want to listen to interesting music? If so, pay!

It should be clear from what has been said above that the situation in science is different: the content that is published by science publishers has already been paid (in most cases). It is the authors' free choice not to use a publisher and keep the price of their publications low, retain the copy and translation rights and offer their work for free download and indexing.

I thank Adam P. for inviting me to write about my views on Open Access. Writing this article made me think about all this much more intensively and I see many things clearer now.

I want to thank all those with whom I have been discussing OA issues over the past years. Special thanks go to Anatol Stefanowitsch who pointed out the existence of createspace to me. The existence of this service made me start our initiative. I thank Mary Dalrymple, Matthias Dannenberg, Christiane Fellbaum, Martin Haspelmath, Bob Levine, Frank Richter, and Stuart Shieber for discussion of and/or comments on this paper. Thanks to Bob Levine for pointers to literature concerning the h-index. I thank Monika Diecks and Remco van Capelleveen for discussing library and infrastructure issues with me. I thank Philippa Cook for the discussion of various aspects of this paper and for proof reading.

I thank Winfried Lechner and Uli Reich for providing information regarding the salaries and living costs in Greece and Brazil, respectively. 
I also thank the writers of Wikipedia. While I require all my students to cite original work rather than referring to Wikipedia, I found Wikipedia extremely useful for the task of writing this article. Which conventional lexicon has an entry for the SM-4? Which 30 volume encyclopedia has entries for recent phenomena like the Pirate Parties? Thanks!

I want to also thank Brigitte Narr who runs the Stauffenburg publishing house. She is a pioneer in allowing me to have my books online as PDF files. I also thank Joachim Jacobs and Alexander Koller who supported the Stauffenburg project financially.

I thank my parents and my parents in law for discussions about the past that refreshed my memory.

Finally, I want to thank my friend Peer Höpfner for making his letters to the Kulturminister ('culture secretary') of the GDR and to the Berliner Zeitung and the custom form in Figure 1 available to me.

\section{REFERENGES}

Jens AllWood, Lars-Gunnar ANDERSON, and Östen DAHL (1973), Logik für Linguisten, number 8 in Romanistische Arbeitshefte, Max Niemeyer Verlag, Tübingen.

Manfred BIERWISCH (1963), Grammatik des deutschen Verbs, number 2 in studia grammatica, Akademie Verlag, Berlin.

Hartmut CzEPluCh (1996), Kasus im Deutschen und Englischen. Ein Beitrag zur Theorie des abstrakten Kasus, number 349 in Linguistische Arbeiten, Max Niemeyer Verlag, Tübingen.

DeUtsche Forschungsgemeinschaft (2010), Pressemitteilung: „Qualität statt Quantität“ - DFG setzt Regeln gegen Publikationsflut in der Wissenschaft, URL http://www.dfg.de/service/presse/pressemitteilungen/2010/ pressemitteilung_nr_07/.

Duden (1996), Die deutsche Rechtschreibung, volume 1, Dudenverlag, Mannheim, Leipzig, Wien, Zürich, 21 edition.

Michael GAmon and Tom Reutter (1997), The Analysis of German Separable Prefix Verbs in the Microsoft Natural Language Processing System, Technical Report MSR-TR-97-15, Microsoft Research, Redmond, WA, URL http ://research . microsoft . com/apps/pubs/default . aspx?id=69549.

Stevan HARNAD and Tim BRODY (2004), Comparing the Impact of Open Access (OA) vs. Non-OA Articles in the Same Journals, D-Lib Magazine, URL http://wWw.dlib.org/dlib/june@4/harnad/06harnad.html. 
Stevan HARnad, Tim Brody, François VAlLières, Les CARR, Steve HitchCock, Yves GingRAs, Charles OPPENHEIM, Chawki HAJJEM, and Eberhard R. HILF (2008), The Access/Impact Problem and the Green and Gold Roads to Open Access: An Update, Serials review, 34(1):36-40.

Karl Erich HeIDOLPH, Walter FLÄMING, and Walter MotSCH, editors (1981), Grundzüge einer deutschen Grammatik, Akademie Verlag, Berlin - Hauptstadt der DDR.

Peer HÖPFNER (1985), Reader's Letter to Berliner Zeitung, URL

http://hpsg.fu-berlin.de/ stefan/Pub/OA-JLM/

1985-Leserbrief-Berliner_Zeitung.pdf.

Joachim JACobs, Arnim von Stechow, Wolfgang SteRnefeld, and Theo VENNEMANN, editors (1993), Syntax - Ein internationales Handbuch zeitgenössischer Forschung, volume 9.1 of Handbücher zur Sprach- und Kommunikationswissenschaft, Walter de Gruyter Verlag, Berlin/New York, NY.

Joachim JACOBS, Arnim VON STECHOW, Wolfgang STERNEFELD, and Theo VENNEMANN, editors (1995), Syntax - Ein internationales Handbuch zeitgenössischer Forschung, volume 9.2 of Handbücher zur Sprach- und Kommunikationswissenschaft, Walter de Gruyter Verlag, Berlin/New York, NY.

Brian W. KERnighAN and Dennis M. RitCHIE (1978), The C Programming Language, Prentice Hall, Englewood Cliffs, NJ.

Reinhard KRECKEL, editor (2008), Zwischen Promotion und Professur. Das wissenschaftliche Personal in Deutschland im Vergleich mit Frankreich, Großbritannien, USA, Schweden, den Niederlanden, Österreich und der Schweiz, Akademische Verlagsanstalt, Leipzig.

Jürgen KuCZYNSKI (1983), Dialog mit meinem Urenkel - Neunzehn Briefe und ein Tagebuch, Aufbau Verlag, Berlin/Weimar.

Jürgen KUNZE (1975), Abhängigkeitsgrammatik, number 12 in studia grammatica, Akademie Verlag, Berlin.

Jürgen KUNZE (1991), Kasusrelationen und semantische Emphase, studia grammatica XXXII, Akademie Verlag, Berlin.

Steve LAWRENCE (2001), Free Online Availability Substantially Increases a Paper's Impact, Nature, 441:521.

Stefan MÜLLER (2008), Head-Driven Phrase Structure Grammar: Eine Einführung, number 17 in Stauffenburg Einführungen, Stauffenburg Verlag, Tübingen, 2 edition, URL

http://hpsg.fu-berlin.de/ stefan/Pub/hpsg-lehrbuch.html.

Stefan MüLLER (2010), Grammatiktheorie, number 20 in Stauffenburg Einführungen, Stauffenburg Verlag, Tübingen, URL http://hpsg.fu-berlin.de/ stefan/Pub/grammatiktheorie.html. 


\section{A Personal Note on Open Access in Linguistics}

Stefan MüLLER (Submitted), Unifying Everything, URL

http://hpsg.fu-berlin.de/ stefan/Pub/unifying.html, ms, Freie Universität Berlin.

Stefan Müller, Pollet SAmvelian, and Olivier Bonami (In Preparation), Persian in Head-Driven Phrase Structure Grammar, URL http://hpsg.fu-berlin.de/ stefan/Pub/persian.html.

Renate PASCH, Ursula BRAUSSE, Eva BREINDL, and Ulrich Herrmann WASSNER (2003), Handbuch der deutschen Konnektoren. Linguistische Grundlagen der Beschreibung und syntaktische Merkmale der deutschen Satzverknüpfer (Konjunktionen, Satzadverbien und Partikeln), number 9 in Schriften des Instituts für deutsche Sprache, Walter de Gruyter, Berlin, New York.

Geoffrey K. PUlLuM (1984), Stalking the Perfect Journal, Natural Language and Linguistic Theory, 2(2):261-267.

Jon RADOFF (2011), Game On: Energize Your Business with Social Media Games, Wiley.

Mike Rossner, Heather VAN Epps, and Emma HiLl (2007), Show Me the Data, The Journal of Cell Biology, 179(6):1091-1092.

Anatol STEFANOWITSCH (2012), Offener Brief an die Contentindustrie, URL http://www.scilogs.de/wblogs/blog/sprachlog/sprachwandel/ 2012-04-06/offener-brief-an-die-contentindustrie/page/4.

Barbara STIEBELs (1996), Lexikalische Argumente und Adjunkte: Zum semantischen Beitrag verbaler Präfixe und Partikeln, number 39 in studia grammatica, Akademie Verlag, Berlin.

Wolfgang WURZEL (1984), Flexionsmorphologie und Natürlichkeit. Ein Beitrag zur morphologischen Theoriebildung, number 21 in studia grammatica, Akademie Verlag, Berlin.

This work is licensed under the Creative Commons Attribution 3.0 Unported License. http://creativecommons.org/licenses/by/3.๑/

\section{(c) BY}

